\title{
Academic Salon
}

I. 生物環境工学に関連する学術用語

\author{
$\mathrm{AI}$ 時代の農業ロボット \\ 野口伸 \\ 日本生物環境工学会理事長 \\ (北海道大学大学院農学研究院教授)
}

はじめに

農林水産省は農林水産業・食品産業分野のロボット導入について, 今後重点的に取り 組むべき分野として以下の 3 技術を挙げている.

(1) GPS 自動走行システム等を活用した作業の自動化

(2) 人手に頼っている重労働の機械化・自動化

(3) ロボットと高度なセンシング技術の連動による省力・高品質生産

本稿では「(1) GPS 自動走行システム等を活用した作業の自動化」(ビークルロボット) と「(2)人手に頼っている重労働の機械化・自動化」（施設内収穫ロボット）について解 説したい.

ビークルロボット

ビークルロボットの社会実装はスタートしたところである. ビークルロボットとはト ラクタ, コンバイン, 田植え機などの車両系のロボットの総称である. ロボットトラク タはじめビークルロボットの基本機能は高精度 GNSS（Global Navigation Satellite System）とジャイロスコープのような姿勢角センサを使用して PC などで作成した作業 計画マップを参照しながら走行誤差 $5 \mathrm{~cm}$ 以下，作業速度も慣行作業以上を可能にする 技術である ${ }^{1)}$. また，ビークルロボットは障害物検出センサ ${ }^{2)}$ を装備し，自動作業中に 人や障害物を検出してアラーム，一時停止，待機など適切な行動をとることもできる. 現在市販化されているビークルロボットは「有人監視下」が前提である。その次のロボ ット技術は，圃場間移動を含む遠隔監視によるビークルロボットとなる．我が国の成長 戦略である「未来投資戦略 2018」にも「遠隔監視ビークルロボット」を 2020 年までに 実現すると明記されている.

フィールドの将来像はロボットが生育状態を認識して最適な作業を行うスマートロボ ットである。 ビークルロボットの知能化を進めて篤農技術に近づけ，人手に頼っている 重労働を軽減するロボットに発展させることは未来の姿である ${ }^{3)}$. 具体例をあげると水 稲, 麦類の作物体の窒素ストレスを認識して最適な追肥作業を行うロボットや作物と雑 草を識別して雑草にだけスポット防除するロボット, さらに病虫害発生個所を見つけ, 被害が広がる前に防除するロボットなどが挙げられる ${ }^{4)}$.これらのスマート化に向けた 課題はセンサにある。作物の窒素ストレス検出センサは実用化されているが，それ以外 の作物・雑草識別, 病虫害予兆検出などのセンサはいまだ開発途上である。ただ，最近 話題のビッグデータ・Al（人工知能）が有効であることから国際的に開発が活発に行わ 
れている，移動のための脚はビークルロボット，目と頭脳は IT 農業技術が担い，この 両者を統合することで「単純作業ロボット」から「スマートロボット」に進化するので ある。ささらに目と頭脳は必ずしもビークルロボットと一体である必要もない。たとえば 目の機能を担うドローンが上空から情報を効率的に収集し，その情報を脳の機能を担う 外部の高性能コンピュータに伝送・解析して，その最終結果だけをビークルロボットに 伝送して精密な作業を行うことも可能である。このような形態をとると個々のロボット に目と脳が不要になり共同利用できるので，ロボットの低コスト化に寄与する。ただ し，これにはIoT 利用が必須である. IoTとは様々なモノがインターネットに接続さ れ，情報交換することにより相互に制御する仕組みであり，複雑なシステムを低コスト に構築できる。このようにスマートロボットの実現には最先端技術であるビッグデー 夕, AI, IoT が基盤になる.

施設内収穫ロボット ${ }^{5)}$

農業現場では施設内で働くロボットの導入も期待されている，施設園芸では育苗，管 理, 収穫, 調製, 出荷などほとんどの作業がいまだ手作業であり, 労働力不足は深刻で ある。たとえばイチゴ生産における育苗, 定植, 管理, 収穫, 調製, 出荷などの合計労 働時間は $10 \mathrm{a}$ 当たり 2,019 時間にもなり, 稲作労働時間の 25 時間 $/ 10 \mathrm{a}$ の 80 倍といっ たデータもある。このような事情からイチゴ収穫ロボットは農研機構農業技術革新工学 研究センターや宇都宮大学などで開発を進めている。イチゴなどの果菜類を収穫するロ ボットを開発する上で必要な要素技術は(1)果実のセンシング技術, (2)果実のハンドリン グ技術，(3)走行技術の 3 つである。走行技術は施設ではレールなどの走行ガイドを敷設 できるので難しくなく，技術課題は果実の「センシング技術」と「ハンドリング技術」 にある。センシング技術とは熟したイチゴを認識して，位置を計測することである。こ の視覚・認識判断機能には技術的に解決すべき課題が多い. Al 利用も研究されている が，いまだ開発途上にある。現状で最も進んだ農研機構のシステムは LED 照明と単眼 カメラでイチゴの着色度合いを判定し，果実位置は 2 眼のステレオカメラで計測する. 果実の採果ハンドは切断刃付き開閉爪がイチゴの果柄部分を検出・切断し，果実を傷め ないように摘み取りができる。ただし収穫は適期果実の 60 ～70\%に留まる。これ は，果実が葉に隠れている場合や果実同士が重なり合っている場合など個々の果実を正 確に認識することが困難だからである．また採果時間も 9 秒／果であり人に比べるとか なり遅い。このようにロボットの性能が人よりも劣ることから, 実はイチゴ収穫ロボッ トには夜間作業させることが望ましい，日中であれば太陽光のもと作業することになる が，晴天，曇天，雨天など天候や時間によって明るさや色合いが変化する。この太陽光 の変化によってイチゴの見え方が変わり，正確な熟度判定は難しい．この問題は夜間に LED 照明を使うと解決できる.

おわりに

日本農業の持続性をロボットによって確保できるかどうかは，今後これら革新技術を 最大限活用できる農業経営組織や作業体系を生み出せるかどうかにもかかっている．基 本的にロボット 1 台は労働者 1 人に相当し, 人手不足の解消に有効であることは明白で ある．実際にはロボットは昼夜を問わず 24 時間連続作業が可能であり，その労働生産 
性は $2 \sim 3$ 人の労働力に匹敵する.今後ロボット技術は国際市場を念頭におき，しかも 要素技術の共通化を図ることで製造コストの削減に努める必要もある.

引用文献

1) Noguchi N. Agricultural Vehicle Robot. Journal of Robotics and Mechatronics. 30(2): 165-172. 2018.

2) Yang L, Noguchi N. Human detection for a robot tractor using omni-directional stereo vision. Computers and Electronics in Agriculture. 89: 116-125. 2012.

3) Noguchi. N. Vehicle automation. In: Agricultural Robots -Mechanisms and Practice-, eds. Kondo N, Mondta M, Noguchi N., Kyoto University Press, Kyoto. 235-319. 2011.

4) Noguchi N. Agricultural vehicle robot. In: Agricultural Automation - Fundamentals and practices-, eds. Zhang Q, Pierce FJ. CRC Press, Boca Raton. 15-39.2013.

5）内藤裕貴. イチゴ収穫ロボット. アグリバイオ. 1(13): 18-22. 2017. 
西欧型太陽光植物工場（愛媛大学植物工場研究センター）の可能性

\author{
羽藤堅治 \\ 日本生物環境工学会・会長補佐・理事 \\ (愛媛大学農学研究科・教授)
}

仁科弘重

日本生物環境工学会・会長

(愛媛大学・理事・副学長)

はじめに

日本での最初の西欧型太陽光植物工場の本格導入は, 今から 30 年ほど前の 1987 年頃 に井関農機株式会社（以下，井関農機）がオランダからシステムを輸入したところから 始まっている．初めに愛媛大学の植物工場研究とのかかわりについて紹介する．愛媛大 学は, 1979 年に「制御化農業実験自習施設」を設置し, スピーキング・プラント・ア プローチ（SPA）の基礎となる環境状況に対する植物応答の実験を本格的に開始し た. 1988 年には橋本康名誉教授を中心に植物工場に関連する教育研究を行う「施設生 産機械学コース」を立ち上げた。2005 年に, 日本学術会議農業環境工学研究連絡委員 会（橋本康委員長）が，「気象変動条件下および人工環境下における食料生産の工場と 安全性」において 4 つの提言を発表し, 愛媛大学ではこれに沿った方向で植物工場の研 究を加速することとなった。その後, 2007 年に経済産業省地域新生コンソーシアム研 究開発事業に採択され，小型ではあるが必要な機能を実装した太陽光植物工場を愛媛大 学農学部内に設置した。 2008 年に経済産業省地域イノベーション創出研究開発事業に 採択された。さらに 2008 〜 2010 年度 J S T 育成研究「植物工場におけるスピーキン グ・プラント・アプローチで成育を担保した植物部位別温度制御システムの開発」に採 択された．ここでは，植物の成育を SPAに基づくセンシング（一部人による計測項目 も含む）を行いながら，冬期においては従来の温室の温度をコストの面からできるだけ 低く設定し成長点付近のみを暖房し，夏期においては細霧冷房などで成長点付近を効果 的に冷やす環境制御システムの開発を行った。これらの事業の性格から，それまで実験 施設としてのイメージが強かった植物工場が実用化へ向けて認知され始めたということ を示唆しているといえる．2009年度には農林水産省の「モデルハウス型植物工場実 証・展示・研修事業」と経済産業書の「植物工場基盤技術研究拠点整備事業」に採択さ れ, 愛媛大学樽味キャンパス内に新たに植物工場を 2 棟設置し, 西条市に 1 棟, 宇和島 市に 5 棟（育苗施設を含む）を設置し, 大規模施設における本格的な研究と課題解決を 開始した ${ }^{1)}$ 。

経済産業省の事業では, SPA に基づく自動センシングのための計測システムの研究 開発と, 環境制御のための植物応答の基礎実験を中心に各種実験を関連企業と継続的に 行っている。成果の一部として「植物成育診断装置」が, 井関農機株式会社より製品化 された。また，農林水産省の事業では，人材育成事業に取り組むと共に，企業コンソー 
シアムと協力し新しい品目への挑戦を行っている.

2011 年には日本学術会議 農業委員会・食料科学委員会合同 農業情報システム分科会 （野口伸委員長）の報告書「知能的太陽光植物工場の新展開」に協力した. 2013 年に植 物工場関連の施設をまとめて愛媛大学植物工場研究センターを設置した。ささらに, 教育 に関しても 2016 年に当時の仁科弘重農学部長を中心に改組を行い名称を「植物工場シ ステム学コース」に変更し, 植物工場に関連する教育研究に取り組むこととなった.

環境制御に関する問題点

日本に輸入された初期の太陽光植物工場においては, 開発国のオランダとの気象条件 などが異なっているため, さまざまな問題を抱えていた，例えば，気温についてである が, トマト栽培の最適温度は 20 から $25^{\circ} \mathrm{C}$ とされているが, オランダでは 1 年を通し てこの気温の上限を超えることはほとんど無い. そのため温度制御は加温中心となる. これに対して日本では，1年の半分ほどが適温よりも高くなるため，高温障害への対応 が不可欠である，他にも害虫による障害や病気の発生が増えるなど, 多くの課題が山積 していた。これらの課題解決には, 環境に対する植物の応答を観察（計測）し，植物の 成育に好適な環境を作り出すこと, つまり, SPAの考え方に基づく計測制御の重要性 を確認した. SPAの研究においては, 開始当初は, センサーの価格も高く大きく, デ ー夕を処理するためのコンピュータも高価で大型であったため, 実験場所は大学の実験 室内に限られることが多かった。近年, センサーの感度や精度の改善や小型化が進み, 解析用のコンピュータの小型化により，実用化が可能となっている。これにより，現在 では植物の生育環境や生体情報を計測する装置の開発が進んでおり，「植物成育診断装 置」等が市販化されるなど計測や診断をする装置の実用化が進んできている。なにより も，スマート化を進めるためには，自動的な情報収集が必要であり，生体情報とその局 所環境のデータ収集の自動化が重要だが，この実現に向けて研究開発を進めている.

これら様々な種類のセンシングされた環境や生体情報, さらに診断された植物成育な

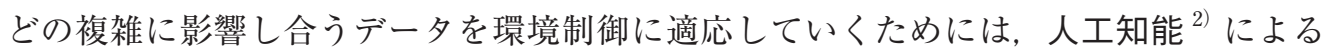
問題解決（制御パラメー夕の決定）が必要であると考えられる。直節制御するまたは考 慮に入れて制御に反映させるべき項目は, 温度制御, 養液制御, $\mathrm{CO}_{2}$ 制御, 湿度制 御, 遮光・補光などによる光量制御など多岐にわたる。これらの制御に用いる制御理論 としては, 論理制御 (逐次制御), フィードバック制御 (線形制御), 比例制御, PID 制 御, シーケンス制御, 適応制御, ファジー制御, 二ューラルネットワーク制御など多く の方法がある. また, その導入方法としては, 単純に従来型のシーケンス制御のパラメ ータをこれらの制御理論によって導き出された設定值に逐次決定する方法が最も容易で 導入しやすいと考えられる，将来的にはアプリケーションの形で容易に組み込めるよう な仕組みが期待される。

栽培品目の拡大と栽培技術の植物工場への適応

栽培品目が露地で栽培されている野菜や作物と比較し少ないことが上げられている. 実験室レベルでは，露地などで一般に生産されている品目に対して植物工場での栽培の 研究は, 多種多様である。しかし, 産業化し採算性の取れる品目は限られている。主な 生産野菜には, トマトのような果菜類を中心に長期間連続して収穫が可能で比較的単価 
の高いものや，葉菜類のように短期間で収穫ができ単価は安いが大量に生産できるとい った傾向がある．植物工場で採算の取れる新しい品目の調査・研究が必要な段階にある と言える.

次に栽培方法に関する知識や技術の普及に関する問題があげられる．植物工場での生 産は, 周年栽培を目的としているために，これまでに培ってきた露地や一般的な施設栽 培での知識や技術をそのまま使用する事が可能なものと, そのままでは使うことが難し いものが混在する。さらに，導入する技術や作業の検討には植物生理に基づく知識と思 考の手順が必要である。新たな品目を植物工場で栽培する場合, 対象作物の栽培方法や 環境デー夕などを元に, トマトの長期多段栽培のような植物工場に適した栽培方法を研 究する必要がある.

近年では, より温暖な地域の作物を栽培する研究するだけはなく, 植物工場の特性を 生かして考えると逆により冷涼な地域の作物も可能であるので, そういった作物の栽培 研究も進んできている.

地域への普及 (教育や啓発活動) ${ }^{3)}$

愛媛大学は農林水産省の事業を継続し, 展示・実証・人材育成についても行ってい る. 実証と展示については，特に大きな問題はないが，人材育成については個人や自治 体における温度差が大きいことを肌で感じている，特に，地元に根ざした中小企業の参 入に関しては，資金面や技術面でのハードルが高いという意見を多く聞くことがある.

人材育成に参加される企業は，(1)先ず話を聞いてみようというところから，(2)導入を考 えていて勉強のためにしている，(3)既に導入済みで問題解決のために来ているところま であり，その興味は多種多様である，農業に携わっている方については，兼業の農家 （企業人）で退職にあわせて本格的に農業をやっていくために情報収集に来られている 方, JA どの経営や現場の指導員で植物工場に将来の農業生産の活路を求めている方 や農家からの質問などに答えるべく勉強に来ている方など多く見られる．しかし県レべ ルの試験場の方の受講となると県によって温度差を感じることがある. 県レベルでの啓 発活動を行う必要があるのではないかと考えているが今のところ人的余裕がないのが現 状である。そこで, 愛媛大学社会連携推進機構（仁科弘重機構長）では, 地域人材育成 を行うための「地域創生イノベーター育成プログラム」を実施しているが，これに講義 を組み込むことによる効果を期待している.

高大連携による啓発活動も重要であると考えている，その理由は，高校の教員が新し い産業形態についてこれていない方が多いと感じている，そのため，植物工場のような 新しい食料生産体系について知識がない方が多いようだ。現状としては，農学関連学部 への進学においてマイナスであると言える。最近マスコミに取り上げられることも多く なってきたが，普通科高校においてはあまり知られていない. 農業高校や総合学科にお いても関連する学科のない高校においては, 先端農業というハードルが高く見え躊躇さ れているようである。 これらの問題を解決するために愛媛大学では, 文科省のスーパー グローバルハイスクール (SGH) やスーパーサイエンスハイスクール (SSH) へ講師 を派遣している．地元高校のスーパ・プロフェッショナル・ハイスクール (SPH) へ の支援も開始している，また，植物工場研究センターは，高校生の実習などにも協力し 
ている. 将来の担い手としても地域に根ざした生徒や学生への啓発活動も必要であると 考えており，地道な努力を続けている.

最後に

植物工場の普及拡大には, 地域による温度差も大きいが, 近年の異常気象（常態化し つつある）の対応も考えると植物工場への期待はますます大きくなっている．植物工場 においては,さらなる環境制御，植物の自動センシング・診断システム開発・社会実装 が期待されている。また，これら技術の社会実装のためには，植物工場に関する啓発活 動を農業者や企業だけではなく，現場で働くことになる若い高校生への広げる必要があ る。また，企業・農業者・団体・自治体との連携の重要であり，これらの活動を続ける ことにより，植物工場とその関連技術が，日本の食料生産の発展に寄与することと考え られる。

参考文献

1）仁科弘重, 有馬誠一, 羽藤堅治, 高山弘太郎. 植物工場技術の研究・開発拉よび実証・展示・教育 拠点 (1) 愛媛大学. 植物環境工学. 24(1):5-9. 2012.

2) 羽藤堅治, 森本哲夫. 知能的植物工場の新展開 [7] - 知能的システム制御一. 農業㧍よび園芸. 85(7): 771-784. 2010.

3)【特集】「かがやく地方創生を目指す愛媛大学地域協働センター西条」, 愛媛大学広報誌ドット・イーフォ リオ：10: 1-14. 2018. 
II. IFAC 委員会

日本における IFAC の活動

(第一回)

IFAC に関するインフォメーション

伊藤博通

日本生物環境工学会 会長補佐・理事

(神戸大学大学院農学研究科教授)

本誌第 30 巻第 2 号から Academic Salonの連載を始めました. Academic Salon には人 工知能 (AI) プロジェクト, IFAC 委員会および生物環境工学に関連する学術用語の 3 つの項目がございます。この度, IFAC 委員会の項目では全 5 回の連載を企画致しまし た。本原稿はその第一回目です. IFAC (International Federation of Automatic Control, 国際自動制御連盟）とは,1956 年ドイツ・ハイデルベルで開催の準備委員会を経て, 1957 年パリで 18 カ国が参加し定款と付則を制定した国際組織です ${ }^{1)}$. 現在 50 力国が 加盟しており，加盟国にNMO（National Member Organization）を組織し，連盟は NMO をメンバーとする国際団体であると定めました。我が国の NMO は日本学術会議 「IFAC 分科会」です.

2023 年にパシフィコ横浜にて IFAC World Congress が開催される予定です．日本生 物環境工学会には計測と制御に関連する研究者が所属しており, 2023 年のWorld Congress には本学会から多数の研究者が参加すると予想されます．IFAC がある意味で 本学会の親であることを本学会員に知っていただくこと，および本学会員から IFACに 関心を持ってもらうことを目的に本連載を企画致しました。

本学会の名誉会長である橋本 康先生は IFAC と非常に関わりが深く, 日本における IFAC 関連学会開催に貢献されてきました。以下は橋本先生からご寄稿いただいた内容 です.

1. 第 8 回 IFAC World Congress 京都大会と椹木 IFAC 会長（京都大学名誉教授（工・ 数理工学)

椹木義一先生は, 我が学会の初期に注目された文部省特定研究「生物環境調節」の諮 問委員として参加され，橋本らが若い頃から，ご指導を仰いだ「システム制御」の世界 的大家で，我が国の計測自動制御学会会長，さらに，IFAC 会長等を歴任された。国際 的にも, 毎年夏に, ウィーン郊外のラクセンブルグの IIASA（国際応用システム分析研 究所）でシステム制御のサマー・セミナーを開催し，IFAC を越えて世界的に多くの教 え子が居る大先生で在り, 94 歳でご逝去.

2. 本学会と IFAC との関係

橋本は IFAC 第 8 回京都世界大会（1981）で農業関係分野のシステム制御に関わる環 境制御の研究成果を発表すべく, 史上初の参画を行い, 日・欄 (Wageningen 大学) ・ 独 (Hannover 大学) の三カ国のグリーンハウスの制御技術者・研究者が参加した。そ 
の成功を受け，日・欄の国際協力に糸口を付け，1990年にはタリーンで開催の第 11 回 世界大会で TC in Agriculture（農業工学分野における国際技術委員会）が承認された。 1991 ～ 1996 年（橋本康：名誉会長）の後を受け，1996～2002 年（村瀬治比古：元本 学会会長)，2008～2014 年（野口伸：理事長）が, TCの委員長を務め, 現在, 清水浩 出版部会長が TC の副委員長に在る。 IFAC は京都世界大会以来 2 度目の世界大会を 2023 年に橫浜で開催予定である.

\section{3 : IFAC に於ける TC 活動の概略}

IFAC は, TC が承認されると, 第 1 回目の国際会議を, その委員長の所在国で開催 し, 以後 3 年毎に当該 TC が責任を持ち, 同一テーマで開催国を変え, 世界中を备り開 催し，学術振興する義務がある。また， 3 年毎に開催の世界大会への発表者を募り，審 査し，大会を盛り上げる責任がある，TCは，1990年に創設以来，最初「Mathematical and Control Application（環境制御システム）」2)，次いで「ポスト・ハーヴェスト・シ ステム」を分割・拡大し，それぞれをシリーズ化し，更に「Artificial Intelligence=



図 1 松山開催の Mathematical and Control Application (1991) の記録 ${ }^{3)}$. 
$\mathrm{AI} 」$ を加え, 10 年ほど蹈襲し，順調な発展を示した．毎年，1，2 回の上記シンポジウ ムを審査し, 開催し，3 年毎には世界大会での枠を死守するために, 上質の論文をコレ クトし, 審査し, 担当の TCの存在が延長されるように, 必死の努力が要請される. $\mathrm{TC}$ 役員は，想像以上のハードワークで，パラダイムの拡張がノルマの全てと云える.

10 余年後の 2002 年から, 様相が変わり, 農業工学の TC は実績と将来像が TB（技 術評議会) で審議, 1 本化され, 将来を見据え,「システム制御 (含む植物工場) 」,「ポ ストハーヴェストプロセス」，「ロボティクス」に拡張された，我が学会の骨子は，成功 を収めている IFAC・TCに依拠している，と言える。

4：IFAC における我が国の活動 ${ }^{3)}$

学術会議 IFAC 分科会が出版した「我が国で開催したIFAC 活動」なる小冊子があ る. 2005 年に, 橋本が農学関係からの理事を引退した節目に, 農学関係から IFAC 役 員を引き継き，学術会議「IFAC」分科会委員として大活躍した村瀬氏（元本学会会 長）が，日本の IFAC 活動を記した小冊子を，学術会議から刊行（2006 年刊）し，その 後, 2011 年に, 増補版を刊行した。その小冊子には，学術会議 IFAC 委員会が実施し た「我が国で開催の関連の多く」が記載されているが, 農業工学分野では, 1991 年 (松山市「愛媛大・橋本」: システム制御), 2001 年 (東京都「東大・瀬尾」: ポストハ ーヴェスト・プロセス)，2006 年（札棍市「北大・野口」：バイオ・ロボチクス）, 2010 年（京都市「大阪府大・村瀬（清水）」: Agri-Control）の開催記録が載せられている.

5 : 農業工学に於ける最初の我が国での IFAC 企画

「農業工学」,「園芸学」,「計測自動制御」を横断するもので在り,「IFAC」のみなら ず「ISHS (国際園芸学会)」も協賛, (支援) 国内組織も多く, 学術振興会, 学術会 議, 農, 工関連学会からもそれらの首脳も参加し（図 1), 最初のセレモニーが大変で あった。

以上が橋本先生からご説明いただいた日本における IFAC 活動の概要です。本連載第 2 回目は2001年東京開催 IFAC Workshop on Control Applications in Post-harvest and Processing の概要を東京大学の大下誠一先生から, 第 3 回目は 2006 年札幌開催 BIOROBOTICS III の概要を北海道大学の野口 伸先生から, 第 4 回目は 2010 年京都開催 AGRICONTROL の概要を京都大学の清水 浩先生からご説明いただく予定です．最終回 は IFACにまつわる今後の期待などについて伊藤編集委員長が述べる予定です.

1） 日本学術会議国際協力常置委員会編. 国際学術団体及び国際学術協力事業報告書 2004 年度報告 書. 172-178. 2005.

2) Hashimoto Y, Day W. Mathematical and Control Applications in Agriculture and Horticulture. Pergamon Press, Oxford. 447. 1991.

3) Murase H. IFAC in Japan (1956-2011). Science Council of Japan. 1-82. 2011. 